\title{
Effect of electrical and controlled atmosphere stunning methods on broiler chicken behavior at slaughter, blood stress indicators and meat traits
}

\author{
Efeito da eletronarcose e do método de insensibilização por atmosfera controlada no \\ comportamento das aves ao abate, nos indicadores sanguíneos de estresse e nas características \\ da carne
}

\section{Marcos Franke PINTO ${ }^{1}$; Diego Augusto BITENCOURT ${ }^{2}$; Elisa Helena Giglio PONSANO ${ }^{1}$; Manoel GARCIA-NETO ${ }^{1}$; Iderlipes Luiz Carvalho BOSSOLANI ${ }^{2}$}

\footnotetext{
${ }^{1}$ Universidade Estadual Paulista "Júlio de Mesquita Filho", Faculdade de Medicina Veterinária, Departamento de Apoio, Produção e Saúde Animal, Araçatuba - SP, Brazil

${ }^{2}$ Universidade Estadual Paulista "Júlio de Mesquita Filho", Faculdade de Medicina Veterinária, Programa de Pós-Graduação em Ciência Animal, Araçatuba - SP, Brazil
}

\begin{abstract}
Brazil is the world's largest exporter and third largest producer of chicken meat. To maintain competitiveness, the productive sector must always be alert to consumer demands, and concern about animal welfare is a growing tendency. Aspects involving animal welfare are especially critical in the slaughter of broiler chickens. This study evaluated the stunning of chickens in a $\mathrm{CO}_{2}{ }^{-}$ enriched atmosphere chamber to reduce bird stress, comparing with electrical water bath stunning, the most usual desensitization method used in chicken slaughter. The reaction of birds when exposed to a high $\mathrm{CO}_{2}$ concentration (30\%) and to a $10 \%$ initial $\mathrm{CO}_{2}$ level, gradually elevated to $30 \%$ was compared. The effect of mixing argon with $\mathrm{CO}_{2}$ was also evaluated, always aiming to reduce the discomfort of birds. In all the gas stunning parameters evaluated, evident discomfort reactions before stunning were observed in about two thirds of the birds, but the blood levels of corticosterone and glucose, used as stress indicators, indicated that gas increased the birds' welfare. Gas exposure time required to stun the birds and time to regain consciousness after exiting the gas chamber presented a wide variation. Controlled atmosphere stunning method facilitated bird handling during slaughter, but more studies will be necessary to develop this technological alternative and make it viable for industrial use.
\end{abstract}

Keywords: Animal welfare. $\mathrm{CO}_{2}$. Stunning. Stress. Human slaughter. Meat quality.

\section{Resumo}

O Brasil é o maior exportador e terceiro maior produtor mundial de carne de frango. A fim de manter a competitividade, o setor produtivo deve estar sempre alerta às exigências dos consumidores e a preocupação com o bem-estar animal é uma tendência crescente. Aspectos envolvendo bem-estar animal são particularmente críticos no abate de frangos de corte. Este estudo avaliou a insensibilização de frangos em uma câmara com atmosfera enriquecida de $\mathrm{CO}_{2}$ para reduzir o estresse das aves, em comparação com a insensibilização elétrica em cuba d'água, o método de atordoamento mais usual no abate de frangos. Foi comparada a reação das aves quando expostas a uma alta concentração de $\mathrm{CO}_{2}(30 \%)$ ou a uma concentração inicial de $10 \%$ de $\mathrm{CO}_{2}$, elevada gradualmente até 30\%. O efeito da mistura de argônio com $\mathrm{CO}_{2}$ também foi avaliado, sempre visando a redução das reações de desconforto das aves. Cerca de dois terços das aves apresentaram reações evidentes de desconforto antes do atordoamento, em todos os parâmetros de insensibilização gasosa utilizados, porém, as concentrações sanguíneas de corticosterona e glicose, usados como indicadores de estresse, indicaram que a insensibilização com $\mathrm{CO}_{2}$ promoveu o bem-estar das aves. O tempo de exposição ao $\mathrm{CO}_{2}$ necessário para o atordoamento das aves e o tempo de recuperação da consciência após a saída da câmara de gás apresentou ampla variação. A insensibilização por atmosfera controlada de $\mathrm{CO}_{2}$ facilitou o manejo das aves durante o abate, mas serão necessários mais estudos para desenvolver essa alternativa tecnológica, de forma a torná-la viável para aplicação industrial.

Palavras-chave: Bem-estar animal. $\mathrm{CO}_{2}$. Insensibilização. Estresse. Abate humanitário. Qualidade de carne. 
Correspondence to:

Marcos Franke Pinto

Universidade Estadual Paulista, Faculdade de Medicina

Veterinária de Araçatuba

Rua Clóvis Pestana, 793

CEP 16050-680, Araçatuba, SP, Brazil

E-mail: mfpinto@fmva.unesp.br

Received: 11/09/2014

Approved: 03/10/2016

\section{Introduction}

Brazil is the world's largest exporter and third largest producer of chicken meat. To maintain competitiveness, the productive sector must always be alert to consumer demands, and concern about animal welfare is a growing tendency. Aspects involving animal welfare are especially critical in the slaughter of broiler chickens. This study evaluated the stunning of chickens in a $\mathrm{CO}_{2}$-enriched atmosphere chamber to reduce bird stress, comparing with electrical water bath stunning, the most usual desensitization method used in chicken slaughter. The reaction of birds when exposed to a high $\mathrm{CO}_{2}$ concentration $(30 \%)$ and to a $10 \%$ initial $\mathrm{CO}_{2}$ level, gradually elevated to $30 \%$ was compared. The effect of mixing argon with $\mathrm{CO}_{2}$ was also evaluated, always aiming to reduce the discomfort of birds. In all the gas stunning parameters evaluated, evident discomfort reactions before stunning were observed in about two thirds of the birds, but the blood levels of corticosterone and glucose, used as stress indicators, indicated that gas increased the birds' welfare. Gas exposure time required to stun the birds and time to regain consciousness after exiting the gas chamber presented a wide variation. Controlled atmosphere stunning method facilitated bird handling during slaughter, but more studies will be necessary to develop this technological alternative and make it viable for industrial use.

\section{Material and Methods}

This study was submitted to and approved by the Committee for Ethical Use of Animals. This ethical statement licenses experiments using animals at the Faculdade de Medicina Veterinária de Araçatuba (FMVA), Universidade Estadual Paulista (FMVA/UNESP), São Paulo, Brazil. This experiment was conducted in the FMVA experimental slaughter plant.

\section{Experimental procedures}

A total of 480 Cobb 50042 day-old broilers were distributed in four treatments (control, that corresponds to the birds before stunning, electronarcosis, $\mathrm{CO}_{2}, \mathrm{CO}_{2}+$ argon) in a completely randomized design with six replications. Birds were submitted to a feed withdrawal period of $6 \mathrm{~h}$ before slaughter. The birds were individually weighed before and after fasting. Then, they were carefully placed in plastic transport crates. The distance between the broiler house and the experimental abattoir was only 200 meters, and transport was carried out in the morning, under mild temperatures. For the gas stunning method, the birds were exposed to an enriched $\mathrm{CO}_{2}$ atmosphere or to a mixture of $75 \% \mathrm{CO}_{2}$ and $25 \%$ argon in a pilot scale stainless steel experimental chamber with an acrylic cover, to allow the observation of birds' behavior during the stunning process. These gases were dispensed from pressurized gas cylinders through appropriate pressure regulators, and the mixture of $\mathrm{CO}_{2}$ and argon was supplied by a gas mixer Model MM-2G, HTK Hamburg. In each cycle of gas stunning, the crates containing five birds each were placed in the stunning chamber, and were submitted to an initial concentration of $10 \% \mathrm{CO}_{2}$, gradually increased to $30 \% \mathrm{CO}_{2}$, for 3 minutes, when this gas was used alone. When $\mathrm{CO}_{2}+$ argon was used, the initial concentration of $\mathrm{CO}_{2}$ was $8 \%$ and it was increased to $23 \%$. The $\mathrm{CO}_{2}$ level was monitored using a Scenty GDZ 203 HTK Hamburg GMBH gas analysis system equipped with a $760 \mathrm{GMF} 0$ to $100 \% \mathrm{CO}_{2}$ sensor inside the chamber. The birds were considered stunned when they fell over and showed no rhythmic breathing or nictitating membrane reflex. The reaction of the birds during the stunning process, the time required to birds' 
desensitization and the time to return to consciousness after stunning were also evaluated.

For the electrical stunning method, the birds were removed from the crates and hung upside down in a pilot scale electrical equipment consisting in overhead rails with metal hooks and an electrified water bath, with capacity to apply electric current to a single bird at a time. The electrical current parameters were fixed at $220 \mathrm{~V} \mathrm{AC}, 60 \mathrm{~Hz}$ and $120 \mathrm{~mA}$ and the exposure time was 5 seconds.

Birds were slaughtered according to the Brazilian laws (BRASIL, 1998; BRASIL, 2000). The difference of weight before and after bleeding was used to estimate the blood drained from the carcasses.

\section{Stress evaluation}

During the exposure to the controlled atmosphere, the behavior of birds was evaluated, and classified as "no reaction", "low reaction", corresponding to weak intermittent wings flapping, gasping and/or head shaking, and "strong reaction", when the birds presented strong continuously wings flapping and/or convulsions. This rating scale was based on the considerations presented by Grandin (2013).

After stunning, at the bleeding, blood samples were collected to determine serum levels of glucose, lactate and corticosterone and compared to the control group, formed by birds which were carefully removed from the crates after transportation and immobilized for collecting blood sample by venipuncture. Blood level of lactate was determined using Roche Accutrend Lactate typ. 3012522 monitor and of glucose using an Optium Xceed monitor with specific test strips. To determine plasma levels of corticosterone, blood samples were transferred into EDTA tubes and kept on ice until plasma was separated by centrifugation $(800 \mathrm{x} g$ for 10 min at $4^{\circ} \mathrm{C}$ ). Plasma samples were stored at $-20^{\circ} \mathrm{C}$ until assayed. Plasma corticosterone concentration was determined using a specific radioimmunoassay kit (MP Biomedicals) (NIJDAM et al., 2005).

\section{Meat traits evaluation}

Considering that the mixture of $\mathrm{CO}_{2}$ and argon did not diminish the discomfort reactions of the birds, argon was not used to study the effect of stunning method in meat characteristics, and the experiments compared $\mathrm{CO}_{2}$ stunning with electrical water bath stunning method.

Postmortem $\mathrm{pH}$ drop was determined in breast and thigh muscles using a meat $\mathrm{pH}$ meter with a penetration probe (Model 1120-X, Mettler Toledo). The color of breast and thigh meat was measured using a portable, reflected-color measurement spectrophotometer (Model Mini Scan XE plus, HunterLab) and expressed as Comission Internationale de l'Éclairage Lab color L (lightness), a (redness), b (yellowness) (CIE, 1986). Warner-Bratzler shear force was determined in breast meat according to American Meat Science Association (AMSA, 1995) using a texture analyzer with a Warner-Bratzler cell (Model TaXT-2i, Stable Micro Systems).

\section{Experimental design and statistical analysis}

To compare bird stress using the stunning method, the experiment was conducted in a completely randomized design with 4 treatments and six replications. All data were analyzed by ANOVA procedures appropriate for completely randomized designs (ZAR, 1992), using the GLM procedure of SAS (2013). Significance of differences among means was tested using Duncan's test (ZAR, 1992). The significance of means was determined at $\mathrm{P}<0.05$.

\section{Results and Discussion}

\section{Effect of stunning method on the birds' stress}

Brazilian law requires at least $30 \%$ of $\mathrm{CO}_{2}$ for the stunning of chickens (BRASIL, 2000). However, when the birds were submitted directly, in both of gases composition - using only $\mathrm{CO}_{2}$ or $75 \% \mathrm{CO}_{2}$ and $25 \%$ argon - to a high initial gas concentration, they 
presented strong discomfort reaction immediately after the introduction of the transport crate inside the gas chamber. This fact was previously reported by Bitencourt (2011). When the birds were submitted to a $10 \%$ initial gas concentration, followed by gradual increase of the gas concentration, as recommended by Nunes (2005), it was necessary 3 minutes after reaching the final concentration to provide an efficient stunning of birds. Other studies using argon and $\mathrm{CO}_{2}$ tested different gas mixture compositions. Webster and Fletcher (2001) used 70\% argon and 30\% CO2; Abeyesinghe et al. (2007) used 60\% argon and 30\% $\mathrm{CO}_{2}$; Raj (1998) recommended $90 \%$ argon in air or $30 \%$ $\mathrm{CO}_{2}$ and $60 \%$ argon. But, according to Nunes (2005), argon costs two to three times more than $\mathrm{CO}_{2}$. So, in the present study, 25\% argon was tested to reduce the unpleasant sensation caused by $\mathrm{CO}_{2}$ acidity during the induction phase, before the loss of consciousness. However, similar discomfort reactions were observed in the birds exposed to $\mathrm{CO}_{2}$ or to $\mathrm{CO}_{2}+$ argon. Thereafter, using argon, the birds required less time to recover consciousness. In an industrial plant, this effect could result in birds recovering consciousness before bleeding. The concentration of lood corticosterone is the most sensitive indicator of stress in broilers (THAXTON et al., 2005). Borges et al. (2003) mention that chickens submitted to heat stress present an increase in glucose blood level, as a direct response to the secretion of adrenaline, noradrenaline and glucocorticoids, including corticosterone. Lactate, as the end product of anaerobic glycolysis, has also been used as a stress indicator of animals at slaughter (BERTOLINI et al., 2006). So, in this study, glucose and lactate blood levels, measured by commercial human portable monitors, were evaluated as more affordable and simpler alternatives to estimate chicken stress, in situations in which the measurement of corticosterone is not possible. Glucose and corticosterone blood concentrations were not different between gas stunned birds and birds at rest $(\mathrm{P}>0.05)$. The level of both blood stress indicators was higher $(\mathrm{P}<0.05)$ when electrical stunning was used (Table 1). Lactate blood concentrations were lower for birds at rest $(\mathrm{P}<0.05)$ but not different for all stunning methods tested $(\mathrm{P}>$ 0.05). Lactate blood level can be affected by decreased levels of oxygen in the blood and tissues. Because of that, it is not a suitable blood indicator for the evaluation of stress when gas stunning is used.

Table 1 - Blood concentrations of corticosterone, glucose and lactate ${ }^{1}$ of broiler chickens according to different stunning methods - FMVA/UNESP - Araçatuba (SP) - 2010

\begin{tabular}{cccc}
\hline Stunning methods & Corticosterone $(\mathbf{n g} / \mathbf{d l})$ & Glucose $(\mathbf{m g} / \mathbf{d l})$ & Lactate $(\mathbf{m m o l} / \mathbf{l})$ \\
\hline Control & $50.65 \pm 22.41^{\mathrm{b}}$ & $305.95 \pm 24.45^{\mathrm{b}}$ & $5.4 \pm 0.94^{\mathrm{b}}$ \\
Electrical & $104.13 \pm 64.39^{\mathrm{a}}$ & $337.65 \pm 41.54^{\mathrm{a}}$ & $7.8 \pm 2.61^{\mathrm{a}}$ \\
$\mathrm{CO}_{2}$ & $72.49 \pm 35.82^{\mathrm{b}}$ & $315.7 \pm 36.51^{\mathrm{b}}$ & $8.13 \pm 0.53^{\mathrm{a}}$ \\
$\mathrm{CO}_{2}+$ Argon & $55.71 \pm 31.38^{\mathrm{b}}$ & $302.45 \pm 31.76^{\mathrm{b}}$ & $7.29 \pm 1.61^{\mathrm{a}}$ \\
\hline${ }^{\mathrm{a}, \mathrm{b}}$ Means in a column with different superscripts differ significantly $(\mathrm{P}<0.05)$ by Duncan's test \\
${ }^{1}$ Mean $\pm \mathrm{SE}(\mathrm{n}=120)$
\end{tabular}

The blood volume drained during bleeding was not different for the stunning methods tested $(\mathrm{P}>0.05)$, ranging from 3.3 to $3.4 \%$ birds weight (Table 2). This finding was important to demonstrate that gas stunning was the cause of animals' death. The loss of weight during feed withdrawal also did not differ among treatments $(\mathrm{P}>0.05)$. This observation was important because weight differences in fasting period could affect the blood glucose level of birds.

Table 2 - Weight loss during fasting and bleeding according different stunning methods of broiler chickens ${ }^{1}$ - FMVA/UNESP - Araçatuba (SP) - 2010

\begin{tabular}{|c|c|c|c|}
\hline & $\mathbf{C O}_{2}$ & $\mathbf{C O}_{2}+$ Argon & Electronarcosis \\
\hline Weight loss fasting (\%) & $6.18 \pm 1.22$ & $6.67 \pm 1.25$ & $5.09 \pm 0.88$ \\
\hline Weight loss bleeding (\%) & $3.37 \pm 0.67$ & $3.37 \pm 0.82$ & $3.26 \pm 0.33$ \\
\hline
\end{tabular}


Vizzier-Thaxton et al. (2010) also observed higher plasma corticosterone levels in electrically stunned birds than in birds stunned in a controlled atmosphere system. In that study, electrically stunned birds presented plasma corticosterone means from 1,600 to $1,700 \mathrm{pg} / \mathrm{ml}$ (or 160 to $170 \mathrm{ng} / \mathrm{dl}$ ) and the birds stunned in a low atmospheric pressure system, 700 to $800 \mathrm{pg} / \mathrm{ml}$ (or 70 to $80 \mathrm{ng} / \mathrm{dl}$ ), nearing the values found in the present experiment.

The weight loss during the fasting period did not differ among the treatments $(\mathrm{P}>0.05)$, indicating that the pre-slaughter management for all birds was homogeneous.

The percentage of blood drained from the carcasses, estimated by the difference of weight before and after bleeding, did not differ among the treatments. Other research papers reported similar results (CRAIG et al., 1999; GÖKSOY et al., 1999).

\section{Effect of stunning method on meat characteristics}

Regarding meat characteristics, final $\mathrm{pH}$ in breast and thigh also did not vary among the different stunning methods $(\mathrm{P}>0.05)$ (Figures 1 and 2). Battula et al. (2008) also investigated the effect of gas stunning on meat quality and reported similar results. Breast meat has a higher proportion of glycolytic fibers and, consequently, presents lower values of final $\mathrm{pH}$ than thigh meat (LAWRIE; LEDWARD, 2006).

Shear force means were 1.35 and $1.46 \mathrm{~kg} / \mathrm{cm}^{2}$ for breast meat samples from birds submitted to gas and electrical stunning, respectively, with no significant difference $(\mathrm{P}>0.05)$. Both means were within the range that corresponds to soft meat, and were compatible with the results reported by McDougall (1994) and Magalhães (2004).

Lightness (L) and redness (a) values found for breasts from electrical stunning showed that they were darker and redder $(\mathrm{P}<0.05)$, probably due to changes in blood pressure (Table 3 ).

Smith and Northcutt (2009) compiled several studies reporting lightness (L value) of broiler breast meat. Comparing these results with our study, $L$ value observed in breast meat samples from the electrically stunned birds can be classified as normal or pale, and the breast meat samples from the birds stunned by gas correspond to pale category.

Table 3 - Color parameters of breast and thigh muscle', according to stunning method - FMVA/UNESP - Araçatuba (SP) - 2010

\begin{tabular}{lccc}
\hline & \multicolumn{3}{c}{ Color $^{1}$} \\
\cline { 2 - 4 } Stunning method / muscle & $\mathbf{L}^{*}$ & $\mathbf{a}^{*}$ & $\mathbf{b}^{*}$ \\
\hline Electrical / breast & $60.55^{\mathrm{b}} \pm 0.41$ & $8.94^{\mathrm{a}} \pm 0.57$ & $16.65 \pm 0.62$ \\
Electrical / thigh & $63.48^{\mathrm{a}} \pm 0.31$ & $8.14^{\mathrm{ab}} \pm 0.09$ & $18.28 \pm 1.71$ \\
$\mathrm{Gas}^{2} /$ breast & $65.48^{\mathrm{a}} \pm 3.23$ & $5.14^{\mathrm{b}} \pm 0.81$ & $14.80 \pm 0.79$ \\
$\mathrm{Gas}^{2} /$ thigh & $60.67^{\mathrm{ab}} \pm 3.24$ & $7.81^{\mathrm{ab}} \pm 0.87$ & $14.61 \pm 0.77$ \\
\hline${ }^{\mathrm{a}, \mathrm{b}}$ Different superscript letters in the same column indicate significant difference by \\
Duncan's test $(\mathrm{P}<0.05)$ \\
${ }^{1}$ Mean $\pm \mathrm{SE}(\mathrm{n}=120) . \mathrm{L}^{*}=$ lightness; $\mathrm{a}^{*}=$ redness; $\mathrm{b}^{*}$ = yellowness. ${ }^{2}$ The transport crate \\
containing five birds was placed in the stunning chamber with an initial concentration \\
of 10\% $\mathrm{CO}_{2}$, gradually increased to 30\% $\mathrm{CO}_{2}$, for 3 minutes
\end{tabular}




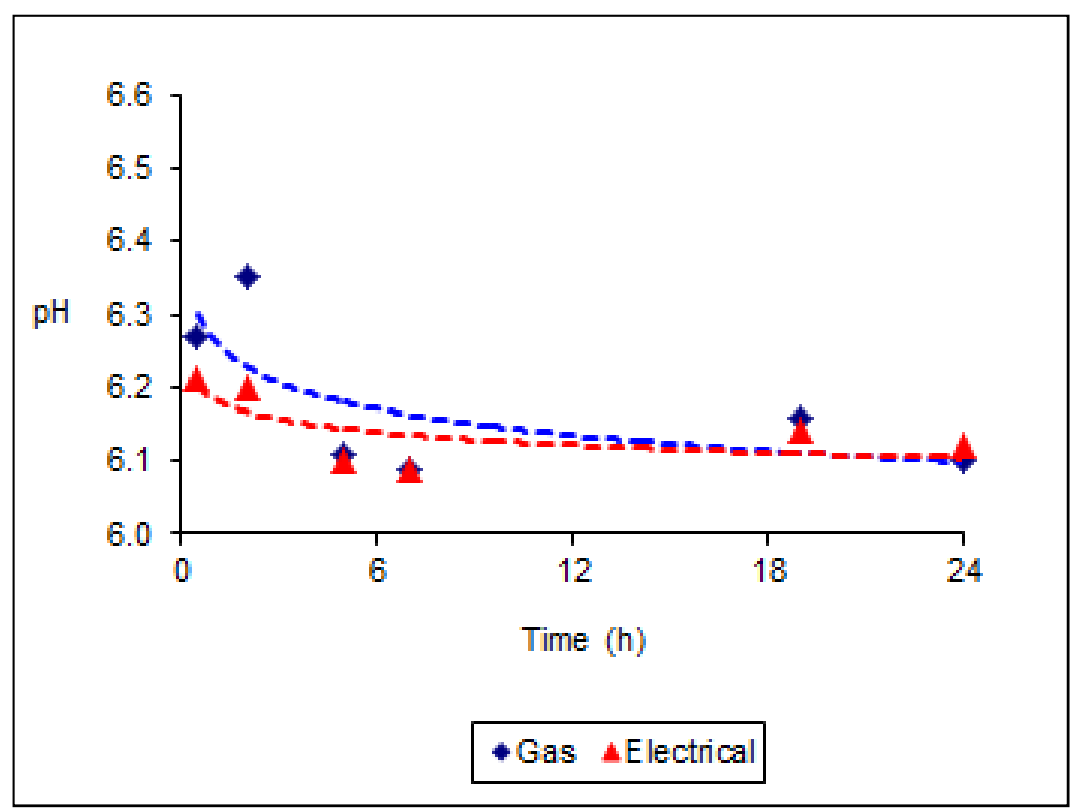

Figure 1 - Postmortem pH drop in breast meat, according to different stunning methods and time after slaughter

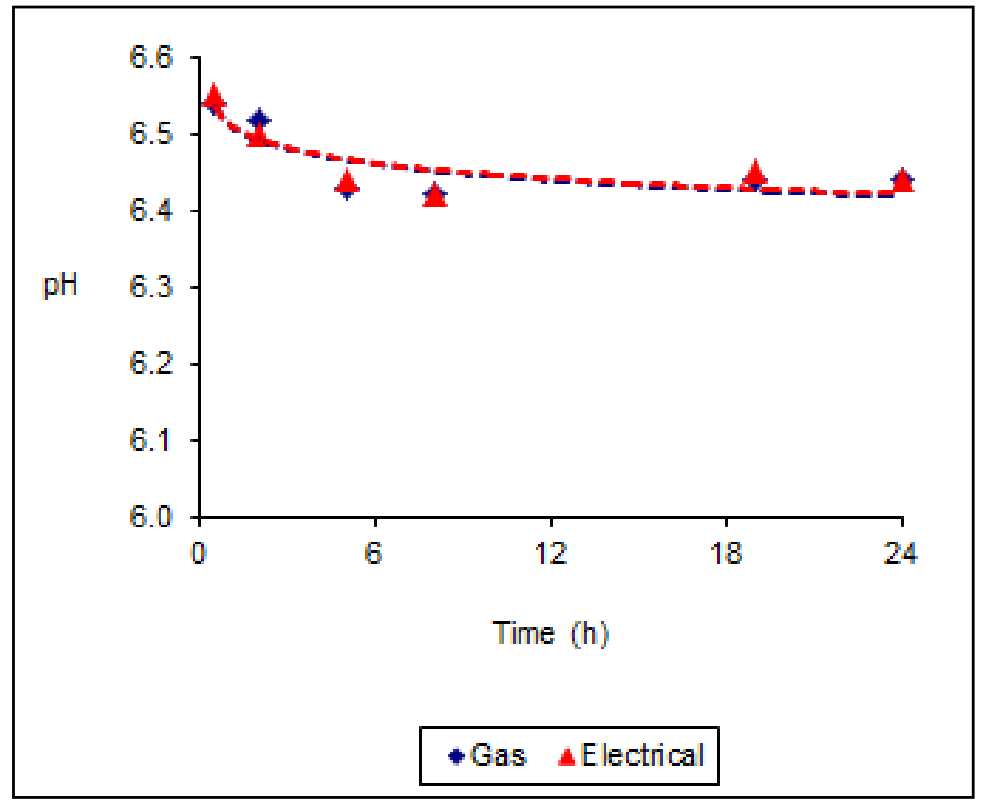

Figure 2 - Postmortem $\mathrm{pH}$ drop in thigh meat, according to different stunning methods and time after slaughter

Grandin (2013) advises that the results observed in the research laboratory may be different compared to how the birds react in an industrial scale. So, this stunning method must be tested in a commercial slaughter scale (MCKEEGAN et al., 2007). In a preliminary trial, the pilot scale gas stunning chamber was tested in a commercial slaughterhouse plant, and the workers responsible for the reception and handling of chickens were asked to freely give their opinion about this alternative stunning method. They all stated that the method can provide comfort for the operators, because birds did not scratch, defecate or struggle when they were removed from the transport crates. It reduces effort, injury hazard and the amount of feces and dust in the room, but, in order to make this method available for a large-scale process, equipment must be developed to avoid delays in the processing line. 


\section{Conclusions}

The controlled atmosphere stunning method reduces the level of blood stress indicators of broiler chicken - glucose and corticosterone - when compared to the electrical water bath stunning method.

The mixture of $25 \%$ argon did not provide additional benefits as compared to the use of $\mathrm{CO}_{2}$ only.

The stunning method - electrical or gaseous - did

\section{References}

ABEYESINGHE, S. M.; MCKEEGAN, D. E. F.; MCLEMAN, M. A.; LOWE, J. C.; DEMMERS, T. G. M.; WHITE, R. P.; KRANEN, R. W.; VAN BEMMEL, H.; LANKHAAR, J. A. C.; WATHES, C. M. Controlled atmosphere stunning of broiler chickens. I. Effects on behaviour, physiology and meat quality in a pilot scale system at a processing plant. British Poultry Science, v. 48 , n. 4, p. 406-423, 2007. doi: $10.1080 / 00071660701543089$.

AMERICAN MEAT SCIENCE ASSOCIATION (AMSA). Research guidelines for cookery, sensory evaluation and instrumental tenderness measurements of fresh meat. Illinois: National Live Stock and Meat Board, 1995. 47 p.

BATTULA, V.; SCHILLING, M. W.; VIZZIER-THAXTON, Y.; BEHRENDS, J. M.; WILLIAMS, J. B.; SCHMIDT, T. B. The effects of low-atmosphere stunning and deboning time on broiler breast meat quality. Poultry Science, v. 87, n. 6, p. 1202-1210, 2008. doi: 10.3382/ps.2007-00454.

BERTOLONI, W.; SILVEIRA, E. T. F.; LUDTKE, C. B.; ANDRADE, J. C. Avaliação de diferentes híbridos suínos submetidos à insensibilização elétrica e gasosa $\left(\mathrm{CO}_{2}\right)$. Parte 1 - mensuração de indicadores sanguíneos de estresse. Ciência e Tecnologia de Alimentos, v. 26, n. 3, p. 564-570, 2006. doi: 10.1590/S0101-20612006000300013.

BITENCOURT, D. Insensibilização de frangos de corte em atmosfera controlada na promoção do bem-estar animal. 2011. Dissertação (Mestrado em Ciência Animal) Faculdade de Medicina Veterinária, Universidade Estadual Paulista, Araçatuba, 2011.52 p.

BORGES, S. A.; MAIORKA, A.; SILVA, A. V. F. Fisiologia do estresse calórico e a utilização de eletrólitos em frangos de corte. Ciência Rural, v. 33, n. 5, p. 975-981, 2003. doi: 10.1590/S0103-84782003000500028. not promote relevant difference in meat traits that might affect meat acceptance by consumers.

\section{Acknowledgments}

This study was supported by FAPESP - São Paulo State Research Support Foundation - Process 2008/52522-2.

BRASIL. Ministério da Agricultura, Pecuária e Abastecimento. Instrução Normativa n³, de 17 de outubro de 2000. Aprova o Regulamento Técnico de Métodos de Insensibilização para o Abate Humanitário de Animais de Açougue. Diário Oficial [da] República Federativa do Brasil, Brasília, DF, 24 jan. 2000. Seção 1, p. 14.

BRASIL. Ministério da Agricultura, Pecuária e Abastecimento. Portaria no 210, de 10 de novembro de 1998. Aprova o regulamento técnico de inspeção tecnológica e higiênico-sanitária de carne de aves. Diário Oficial [da] República Federativa do Brasil, Brasília, DF, 26 nov. 1998. Seção 1, p. 226.

COMMISSION INTERNATIONALE DE L'ECLAIRAGE (CIE). Colorimetry. Viena: CIE Publications, 1986. 78 p.

CRAIG, E. W.; FLETCHER, D. L.; PAPINAHO, P. A. The effects of antemortem electrical stunning and postmortem electrical stimulation on biochemical and textural properties of broiler breast meat. Poultry Science, v. 78, n. 3, p. 490494, 1999. doi: 10.1093/ps/78.3.490.

GÖKSOY, E. O.; MCKINSTRY, L. J.; WILKINS, L. J.; PARKMAN, I.; PHILLIPS, A.; RICHARDSON, R. I.; ANIL, M. H. Broiler stunning and meat quality. Poultry Science, v. 78 , n. 12, p. 1796-1800, 1999. doi: 10.1093/ps/78.12.1796.

GRANDIN, T. Animal welfare evaluation of gas stunning (controlled atmosphere stunning) of chickens and other poultry. 2013. Available from: <https://goo.gl/1KCjPs>. Viewed: 23 Nov. 2015.

LAWRIE, E.; LEDWARD, D. (Eds.). Lawrie's meat science. $7^{\text {th }}$ ed. Cambridge: Woodhead, 2006. 464 p. 
MAGALHÃES, P. C. Efeitos da utilização de proteínas de origem vegetal em substituição a proteína de origem animal sobre a absorção de água da carcaça e maciez do músculo pectoralis major em frangos de corte. 2004. $30 \mathrm{f}$. Dissertação (Mestrado em Ciências Veterinárias) - Setor de Ciências Agrárias, Universidade Federal do Paraná, Curitiba, 2004.

MCDOUGALL, D. B. Color of meat. In: PEARSON, A. M.; DUTSON, T. R. Quality attributes and their measurements in meat, poultry and fish products. Glasgow: Blackie Academic \& Professional, 1994. p. 79-93.

MCKEEGAN, D. E. F.; ABEYESINGHE, S. M.; McLEMAN, M. A.; LOWE, J. C.; DEMMERS, T. G. M.; WHITE, R. P.; KRANEN, R. W.; VAN BEMMEL, H.; LANKHAAR, J. A. C.; WATHES, C. M. Controlled atmosphere stunning of broiler chickens. II. Effects on behaviour, physiology and meat quality in a commercial processing plant. British Poultry Science, v. 48, p. 430-442, 2007. doi: 10.1080/00071660701543097.

NIJDAM, E.; DELEZIE, E.; LAMBOOIJ, E.; NABUURS, M. J. A.; DECUYPERE, E. STEGEMAN, J. A. Comparison of bruises and mortality, stress parameters and meat quality in manually and mechanically caught broilers. Poultry Science, v. 84, n. 3, p. 467-474, 2005. doi: 10.1093/ps/84.3.467.

NUNES, F. Atordoamento é qualidade e rendimento. AveWorld, 2005. Available from: <https://goo.gl/dqAWh0>. Viewed: 25 Nov. 2015.
RAJ, M. Welfare during stunning and slaughter of poultry. Poultry Science, v. 77, n. 12, p. 1915-1819, 1998.

STATISTICAL ANALISYS SYSTEM. (SAS). Institute Incorporation. The SAS System release 9.3. Cary: SAS, 2013.

SMITH, D. P.; NORTHCUTT, J. K. Pale poultry muscle syndrome. Poultry Science, v. 88, n. 7, p. 1493-1496, 2009. doi: 10.3382/ps.2008-00509.

THAXTON, J. P.; STAYER, P.; EWING, M.; RICE, J. Corticosterone in commercial broilers. Journal of Applied Poultry Research, v. 14, n. 4, p. 745-749, 2005. doi: 10.1093/japr/14.4.745.

VIZZIER-THAXTON, Y.; CHRISTENSEN, K. D.; SCHILLING, M. W.; BUHR, R. J.; THAXTON, J. P. A new humane method of stunning broilers using low atmospheric pressure. Journal of Applied Poultry Research, v. 19, n. 4, p. 341-348, 2010. doi: 10.3382/japr.2010-00184.

WEBSTER, A. B.; FLETCHER, D. L. Reactions of laying hens and broilers to different gases used for stunning poultry. Poultry Science, v. 80, n. 9, p. 1371-1377, 2001. doi: 10.1093/ps/80.9.1371.

ZAR, J. H. Biostatistical analysis. $4^{\text {th }}$ ed. New Jersey: Prentice-Hall, 1992. 930 p. 